Article

\title{
Is There Room for Targeting within Universalism? Finnish Social Assistance Recipients as Social Citizens
}

\author{
Paula Saikkonen ${ }^{1, *}$ and Minna Ylikännö ${ }^{2}$ \\ ${ }^{1}$ Social Policy Research, Finnish Institute for Health and Welfare, 00271 Helsinki, Finland; E-Mail: paula.saikkonen@thl.fi \\ ${ }^{2}$ Kela-Social Insurance Institution of Finland, 00250 Helsinki, Finland; E-Mail: minna.ylikanno@kela.fi \\ * Corresponding author
}

Submitted: 30 September 2019 | Accepted: 27 January 2020 | Published: 18 March 2020

\begin{abstract}
This article focuses on the role of means-tested social assistance in Finland, which is often considered one of the Nordic welfare states described as having a universal welfare model. The article scrutinises the capacity of the final safety net to enhance the social citizenship of social assistance recipients. The Finnish social security system combines social insurance (earnings-related benefits), universal benefits (flat-rate benefits), free or affordable public services, and social assistance as a means-tested and targeted element, and thus it is a discussion on the degree of universalism that best captures the nature of universalism in the Finnish welfare state. Because the final safety net includes public services (especially social work) and income transfers (especially social assistance), its ability to strengthen social citizenship depends on both elements-separately and as a combination-as there may be a simultaneous need for financial aid and services. Whilst national registers provide data on social assistance, there is no national register data on municipal social services, which is why a survey was conducted. In this study, the heterogenic clients supported by the final safety net were described based on an open-ended question in the survey data. Statistics were then used to evaluate the frequency of client groups (capable clients, persistent clients, invisible clients, safety net dropouts). The article concludes that universalism as a social policy principle is challenged by the diversity of the clientele.
\end{abstract}

\section{Keywords}

social assistance; social citizenship; social security; universalism; welfare state

Issue

This article is part of the issue “'Universalism' or 'Universalisms' in Social Policies?” edited by Monica Budowski (University of Fribourg, Switzerland) and Daniel Künzler (University of Fribourg, Switzerland).

(C) 2020 by the authors; licensee Cogitatio (Lisbon, Portugal). This article is licensed under a Creative Commons Attribution 4.0 International License (CC BY).

\section{Introduction}

The Nordic welfare states are characterised by a strong emphasis on universalism to promote equality. As a departure from the concept of British universalism, which focuses mainly on the benefits system, universalism in the Nordic welfare states extends to policy outcomes by emphasising the role of public services in increasing equality and social citizenship (Anttonen, Häikiö, Stefánsson, \& Sipilä, 2012). Throughout the development of the Western welfare states, it was disputed how public resources should be used in order to allevi- ate poverty and reduce inequality in society (Petersen, 2011). In general, the influence of earnings-related benefits on equality has been widely questioned, whereas flat-rate benefits have gained more acceptance (Korpi \& Palme, 1998; van Oorschot \& Roosma, 2017). As regards to the Nordic welfare states, which are often described as universal welfare models, the social security systems combine social insurance (earnings-related benefits), universal benefits (flat-rate benefits), free or affordable public services, and also some means-tested elements (Anttonen \& Sipilä, 2012; Kuhnle, 2011). Our starting point is this idea of 'varieties of universalism' 
(Anttonen, Häikiö, Stefánsson, \& Sipilä, 2012, p. 2). We focus on targeting within universalism in the Finnish welfare state, and we scrutinise the capacity of the final safety net to enhance the social citizenship of social assistance recipients. By social citizenship, we mean the right to maintain a reasonable standard of living when social risk is realised (e.g., unemployment, retirement, or illness), as it is used as a policy concept in the field of social security (Eggers, Grages, \& Pfau-Effinger, 2019).

Even though the 'universal welfare state' is a widely used concept, defining universalism is extremely difficult in terms of concrete welfare policies (Goul Andersen, 2012). In addition, it has to be acknowledged that even though there are similarities between the Nordic countries, their social security systems, including minimum income schemes, have developed differently (Kettunen \& Petersen, 2011). We interpret universalism as a principle of social policy according to which people in the same situation should be treated the same, and as characteristic of the Nordic welfare state (Anttonen, Häikiö, Stefánsson, \& Sipilä, 2012). Our interest lies in the social citizenship of one disadvantaged group: social assistance recipients. In the Finnish context, the final safety net is part of the social security system, including services (Niemelä \& Salminen, 2006). In the past, one common character of social assistance in the Nordic countries has been the tight connection between cash and care (Kuivalainen \& Nelson, 2012). Last-resort social assistance and related services come into use once earningsrelated or residence-based basic social benefits (such as unemployment benefits, pensions, and student allowances, which are primary social security against social risks) and universal public services have failed to provide social protection.

Finland is an interesting case, as it goes against the current trend of decentralisation in Europe. This is because in 2017 it centralised social assistance from municipalities under one national agency, the Social Insurance Institution of Finland (Kela). One major justification for the reform was that it would increase equality, as means-tested financial aid would be granted according to the same principles across the country with less discretion. Discretion and local practices were seen to cause unequal outcomes for social assistance recipients (Parliament of Finland, 2014a). Although social services and a small part of social assistance (supplementary and preventive) are still the responsibility of the municipalities, in practice the connection between cash (basic social assistance) and care (social work) became weaker following the reform (Varjonen, 2020). The idea of increasing equality by decreasing the use of discretion in the final safety net may at first sound like something that strengthens universalism in the Finnish welfare state. However, as we discuss universalism as a social policy principle that also covers the outcomes of the policy, the picture becomes blurrier.

In the next section, we discuss universalism and social citizenship in the final safety net. Universalism and social citizenship are both slippery concepts. However, as our focus is on universalism as a social policy principle, we see that these concepts have two common denominators to be considered: membership (inclusion) and allocation (redistribution). After defining these main concepts, we briefly describe the final safety net in the current social security system. We then proceed to describe our research design and results. In the final section, we answer our research questions and reflect on the current state of the Finnish welfare state and its degree of universalism.

\section{Universalism as a Social Policy Principle and Social Citizenship}

In this article, universalism is considered as a social policy principle that also characterises the Nordic welfare model. Universalism provides common access to public goods and supports citizens' social rights (Anttonen, Häikiö, Stefánsson, \& Sipilä, 2012, pp. 3-4; Anttonen, Häikiö, \& Stefánsson, 2012, p. 187). In practice, universal welfare states provide benefits and services for all in order to increase equality, but targeting within universalism might also be an effective redistribution tool (e.g., Goul Andersen, 2012; Jacques \& Noël, 2018; Leibetseder et al., 2017) when improving the lives of less privileged people so that they may reach the general standards of society (Anttonen \& Sipilä, 2012). In this sense, targeting benefits or services may strengthen social citizenship.

\subsection{Interpreting Universalism as a Social Policy Principle}

When universalism is considered as a social policy principle of the welfare state, it has two main dimensions: inclusion and allocation. In the inclusion dimension, universalism includes everyone with welfare needs on the basis of citizenship or residency. In this sense, universalism in the Nordic welfare states can be questioned as it does not include everyone. For instance, asylum seekers are excluded while they wait for the decision on their residence permit application, not to mention asylum seekers with negative decisions who have access only to very limited services. In the allocation dimension, universalism is juxtaposed with selectivism. Selectivism means the discretionary allocation of benefits and services, whereas universalism follows a principle that people in the same situation must be treated in the same way (Anttonen, Häikiö, Stefánsson, \& Sipilä, 2012; Kildal \& Kuhnle, 2005; see also Frederiksen, 2018). However, this juxtaposition is partly arbitrary, as a universal social policy does not mean the absence of targeted benefits and services (Goul Andersen, 2012; Jacques \& Noël, 2018).

Universalism emphasises the delivery of welfare to all on equal terms, but it does not entail that everybody receives the same benefits and services (Anttonen, Häikiö, Stefánsson, \& Sipilä, 2012, pp. 3-4). Typically, discretion and means-testing are used in the final safety net. The principal idea is to give those with welfare needs not only access to a minimum standard of income but also to 
support the less privileged so they can get closer to the general standards of society (Anttonen \& Sipilä, 2012). This means that people with greater needs may receive higher benefits (Anttonen, Häikiö, Stefánsson, \& Sipilä, 2012 , p. 7). The Finnish welfare state is typically labelled as universal rather than residual or selective, in contrast to Anglo-Saxon countries. The earnings-related benefits in the social security system have even increased the legitimacy of the universal welfare model. It has been noted that people are more supportive of benefits that they may get themselves than they are towards strictly targeted benefits (van Oorschot \& Roosma, 2015). The delivery of welfare to all on equal terms does not exclude earnings-related benefits, yet it assumes that all people have equal access to the system (Anttonen, Häikiö, Stefánsson, \& Sipilä, 2012, p. 8).

As a part of the Finnish social security system, social assistance can be seen as targeting within universalism, if targeting results in privileged support for the least well-off (Goul Andersen, 2012). Social assistance combines cash benefits and social services with the objective of meeting the needs of recipients in terms of enhancing their capabilities to participate in society (Ministry of Social Affairs and Health, 1997). Next, we move on to discuss universalism as a form of common access to public goods and citizens' social rights.

\subsection{Social Citizenship and the Final Safety Net}

The dimensions of inclusion and allocation also appear in social citizenship. The concept of social citizenship has been used widely and in varying ways since T. H. Marshall. Most authors agree that the main elements are social rights and responsibilities (Eggers et al., 2019; Marchal, Marx, \& van Mechelen, 2014). These rights and responsibilities formulate a society or community, and thus they influence and determine identities. Indeed, the concept is questioned by arguing that since Marshall, the world has radically changed and better models for citizenship are needed in order to tackle the challenges of multiculturalism, ethnic diversity, and migration (Turner, 2009). Diversity is also a challenge for universalism as a social policy principle (Anttonen, Häikiö, Stefánsson, \& Sipilä, 2012, pp. 8-9).

The idea of universal social citizenship that has been seen as the core of universal social policy has been rivalled by the idea of active citizenship (Anttonen, Häikiö, Stefánsson, \& Sipilä, 2012, p. 10). Active citizenship means strengthening self-responsibility. In the field of social policy, the demand of active citizens has been seen on labour market policies, pension policies, family policies, and long-term care policies, although there are huge variations between countries as to what extent they expect these policies to promote the autonomy and agency of citizens. Active citizenship does not automatically mean that the responsibility of the state (or public responsibility) is replaced by self-responsibility because the state or public sector may support active social citi- zens by offering social security and services that increase citizens' choices and autonomy (Eggers et al., 2019).

Social citizenship has been studied in the context of minimum income schemes, as they define what social citizenship minimally entails. Social rights are often defined as a generosity of benefits (Marchal et al., 2014). However, free public services may bring security and opportunities for citizens and strengthen participation (Gough, 2019). One of the main tasks of minimum income schemes is to alleviate economic hardships, and free services may be a valuable addition to the benefits (Marchal et al., 2014). That is to say, the role of services for social citizenship might be easily ignored, although previous research has highlighted that social assistance arrangements often reflect the level of social citizenship (Leibetseder et al., 2017). To give one example of arrangements: Means-tested social assistance in the Nordic countries is granted mostly for households, but it could be granted to individuals and without any meanstesting at all. The inclusiveness or exclusiveness of the outcome of means-testing can be seen as an indicator of the degree of universalism (Goul Andersen, 2012).

\subsection{Social Assistance as Part of the Finnish Social Security System}

When the social assistance reform was developed (2014-2016), it was argued that centralising social assistance in one national agency would increase the equality of recipients, even though the concept of equality was not clearly defined in the policy documents (Varjonen, 2020). As Kela handles residence-based basic social security benefits, it would be less stigmatising to apply for social assistance from Kela (Parliament of Finland, 2014a). Another reason to promote reform was the large number of social assistance recipients. Many claimants may be dependent on social assistance due to the inadequacy of basic social security benefits (National Institute for Health and Welfare [THL], 2019a).

Finnish social security can mainly be divided into two groups. Firstly, employment-based benefits (e.g., earnings-related pensions, earnings-related sickness benefits and rehabilitation allowances, earnings-related maternity, paternity and parental allowances, and earnings-related unemployment benefits), and secondly, benefits based on residence in Finland (e.g., guarantee pensions, minimum sickness allowances, minimum maternity, paternity and parental allowances, basic unemployment allowance, and labour market subsidy). These basic social security benefits are administered by Kela. Basic social security is meant to secure at least basiclevel income and a reasonable standard of living for everyone, without income or means-testing (THL, 2019a). Therefore, it is assumed that social assistance provides only short-term support (Bradshaw \& Terum, 1997). The inadequacy of basic social security combined with high housing costs in the central districts easily results in financial difficulties (THL, 2019a). 
The reform was enacted in two bills, one in 2014 and the other in 2016. When processing the first bill in Parliament, the Social and Health Committee stated that an operating model that referred clients smoothly and efficiently between two organisations-the municipalities and Kela-was essential for the social inclusion of disadvantaged clients. The committee emphasised that the reform would have a massive effect on social work even though the benefits officers were a known occupational group in most of the municipalities (Parliament of Finland, 2014b). Two years later, the committee stated its disappointment that the model mentioned in the first memorandum was still missing just two months prior to the implementation of the reform (Parliament of Finland, 2016). The importance of referrals was noted, but the lack of practices in the matter was not a reason to postpone the implementation of the reform.

Social assistance is only meant to be a temporary relief when households face financial difficulties. According to the present legislation, the minimum level of social assistance can be reduced by up to $40 \%$ and for two months at a time in cases where an able-bodied applicant is not actively searching for work or participating in active labour market actions. Until the reform, municipal caseworkers rarely used this opportunity to reduce social assistance. The Act on Social Assistance (Ministry of Social Affairs and Health, 1997) emphasises that sanctions should only be carried out if it does not endanger coping with everyday life.

In practice, the reform means that everyone needs to apply for basic social assistance from Kela before they can apply for preventive or supplementary social assistance from a municipality. Basic social assistance can be applied for through an online form, although telephone and in-person services are also available. Kela is responsible for informing the municipality if it realises that a client is in need of social services. However, it is strictly regulated under what circumstances Kela is allowed to contact a municipality without the client's permission.

\section{Research Design}

In this study, we focus on two main questions. Firstly, what is the role of social assistance in the Finnish welfare state? Secondly, what is the nature of universalism in the final safety net? As the final safety net includes public services (especially social work) and income transfers (especially social assistance), its ability to strengthen social citizenship depends on both elements, separately and in tandem, as there may be a simultaneous need for financial aid and services. Unlike basic social security, the last-resort social assistance is means-tested; thus, officials have some discretionary power and impact on how the final safety net is realised (Kallio \& Kouvo, 2015). Traditionally, social workers have been on the front line when assessing the need for social assistance or social services, although even before the basic social assistance was transferred to Kela, there were benefits officers in the municipalities. In most of the municipalities, the benefits officials belonged to teams along with social workers (Blomgren et al., 2016). Thus, the connection between services and income transfers was tighter than after basic social assistance was centralised.

As the interest lies in the final safety net-which includes services and financial aid-we utilised survey data and statistical data: official national social assistance statistics provided by the THL and statistics on basic social assistance provided by Kela. Whereas the latter database only includes information on the basic social assistance, the supplementary and preventive social assistance granted by the municipalities are reported only in the official statistics.

National statistics on social assistance are collected on an annual basis; they include data about basic, preventive and supplementary social assistance (THL, 2019b). Since the reform, Kela (2019) has provided more specific data about basic social assistance a few weeks after benefit claims and payments. However, we have very little data on how social work and other municipal services are organised and how the administration varies between Finnish municipalities. Due to this, we approached THL to collect survey data from the municipalities. It focused on the services of adult social work in the municipalities.

The electronic survey was conducted by the THL in the autumn of 2017 . Some 369 social services caseworkers responded to the survey. Of the responses, $25 \%$ came from the Helsinki metropolitan area, whereas $21 \%$ of the population in mainland Finland lives in this area. Hence, the Helsinki metropolitan area was over-represented. Of the respondents, $37 \%$ worked in the six largest cities in Finland (Helsinki, Espoo, Tampere, Vantaa, Oulu, and Turku), $25 \%$ in medium-sized towns, $33 \%$ in other municipalities, and $5 \%$ chose not to say. Because there is no exact information on the total number of social service caseworkers working with adults with a connection to social assistance in Finland, it is impossible to provide the response rate.

In this article, we focus on the open-ended question that asked the caseworkers about their views regarding who or which client groups had benefitted from the reform and in what way-or whether the caseworkers thought there were clients who had suffered from the reform. From a total of 369 respondents, 252 answered this question. The length of the answers varied from very short (only a few words) to several sentences long. Caseworkers identified several advantages and disadvantages in their responses, often with several issues in one answer. The answers were analysed using ATLAS.ti software, designed for the analysis of qualitative data. The initial coding was based purely on the data and coding advantages and disadvantages (Friese, 2014). Afterwards, the codes were classified into categories according to how the respondents expressed the connection between services and financial aid in the final safety net. The role of social assistance in social work practices has been an on-going discussion since the first social assistance law in 
the 1980s. There was high expectation that social workers would be able to use more time for client work after Kela took care of basic social assistance.

Based on qualitative data, we created a typology of clients. However, it was not possible to provide any information on the number of clients in the different categories based on the survey data. So, we relied on quantitative data on the clientele. The challenge is that not every social assistance recipient needs the services, and not everyone who needs the services is a social assistance recipient. We cannot expect that everyone entitled to social assistance applies for it or is able to access social services. Obviously, the estimates on the number of clients are rough, but useful when considering the degree of universalism in the Finnish welfare state.

\section{Social Citizenship and the Nature of Universalism in the Final Safety Net}

We start by presenting the typology based on the responses to the open-ended question given by the social services caseworkers. As stated above, some of the public services are included as part of social security. For those relying on the final safety net, the services may be even more important. For instance, meeting the basic needs of citizens for health, care, education, and minimum income is at the core of social rights (Gough, 2019). At least in theory, social assistance (financial aid and services) can support these social rights and thus social citizenship as a whole (Leibetseder et al., 2017). After presenting the typology, we find out how these categories appear in the statistics.

\subsection{The Change of System and Heterogeneity of the Clientele}

We received 252 responses to the open-ended question in the questionnaire directed at caseworkers. Unexpectedly, the caseworkers focused more on the client groups and different types of clients who have suffered from the reform than beneficiaries who were mostly described as capable clients. The latter part of the question ('in what way') gave much more information than just the client group. The answers focused mostly on describing unsatisfied service needs, problems in applying or getting social assistance, and outcomes for the clients when the final safety net was not as tight as it should be. As the final safety net is realised as a combination of cash (social assistance) and care (social work), the responses were classified according to these dimensions. The typology is based on the caseworkers' views on their clientele's need for social assistance and services. The classification is summarised in Table 1.

In the top left-hand corner, the need for cash (social assistance) and care is relatively small. This group consists of clients who supplement earnings-related or basic social security with social assistance, which means they do not have assets or wealth. We expected Kela's database to capture this group quite well. Typically, caseworkers stated: 'Self-motivated clients have benefited, as all benefits are paid by Kela' (e.g., Respondent 23, metropolitan area). These criteria fit some older clients, such as long-term unemployed people who are close to pensionable age, some pensioners, and single parents on parental allowances. One social worker wrote:

Those who live in a stable economic situation and whose income and costs do not vary from one month to another have benefitted from the reform. (Respondent 19, medium-size town)

These recipients understand the system and the calculations on which social assistance is based in order to check that the paid amount is correct and if not, they can make a claim for a correction themselves. These were people with stable but low incomes or steady life circumstances. A basic requirement to function independently is having access to the Internet and sufficient skills to use digital services. However, they apply for basic social security and then social assistance, and in return they get a top-up on benefits, assuming they do not have any assets or wealth. Even though there is a benefits official to manage electronic applications, there is no direct interaction between the caseworker and the client if the

Table 1. Classification of clients according to the dimensions of cash and care.

\begin{tabular}{lll}
\hline $\begin{array}{l}\text { Need for cash } \\
\text { (social assistance) }\end{array}$ & \multicolumn{2}{c}{ Need for care (services) } \\
\cline { 2 - 3 } Little & $\begin{array}{c}\text { Little } \\
\text { Capable clients with digital skills and good social } \\
\text { relationships, need for financial aid resulting } \\
\text { from insufficiency of the earnings-related or } \\
\text { basic social benefits combined with high housing } \\
\text { costs, basic social assistance often enough. }\end{array}$ & $\begin{array}{l}\text { Invisible clients such as immigrants without } \\
\text { language skills (Finnish/English/Swedish), } \\
\text { clients with reduced social assistance, } \\
\text { expecially adolescents, clients who avoid } \\
\text { using services. }\end{array}$ \\
& $\begin{array}{l}\text { Persistent clients: Occasional need for basic } \\
\text { social assistance, due to health care or medicine } \\
\text { costs (e.g., pensioners), sometimes need for } \\
\text { supplementary social assistance, rent arrears. }\end{array}$ & $\begin{array}{l}\text { Safety net dropouts: people with accumulated } \\
\text { social problems, long-term social assistance } \\
\text { receipts, elderly people in remote areas } \\
\text { (often in need of preventive social assistance). }\end{array}$ \\
\hline
\end{tabular}


electronic form is correctly filled in. This may be a practice that strengthens social citizenship (e.g., Leibetseder et al., 2017).

In the lower left-hand corner, the need for care (social services) is relatively low, but cash is essential to avoid incapacity or to gain the most basic social rights (Edmiston, 2017). The caseworkers mentioned those clients who only need temporary support, for instance, while waiting for decisions on earnings-related benefits. Pensioners on a disability pension or older people who do not have the skills or equipment to apply for basic social assistance, but who live in the central districts, can be categorised here too. As one social worker wrote:

I thought [before the centralisation] that pensioners with low income would have benefited. But now it seems that applying for social assistance, with all the reporting and attachments, is too difficult for them. (Respondent 56, small town)

These clients do not necessarily need a long-term relationship with the social worker, but they do need periodic help with the application process. They cannot cope with the application process without support from a caseworker, their relatives, an NGO, or Kela staff. For them, the need for social assistance is occasional but may be of critical importance, for instance, to obtain medicine. One caseworker wrote: 'I am most worried about people on disability pensions and people who are not able to use electronic services or cannot read and understand guidelines independently' (Respondent 46, metropolitan area). In this group, social citizenship may be realised if support during the application process is available, the decision concerning basic social assistance is made within seven days (as it should be), and the decisions do not include any major mistakes. The recipients must have a negative or positive decision made for them concerning basic social assistance before applying for supplementary social assistance from the municipality. In this group, public services are needed to ensure income transfers. Social citizenship may be endangered without proper help.

In the upper right-hand corner, the invisible clients are people who can get left out if they do not want to meet any officials and do not care about the reductions to their social assistance payments. However, from this angle, it can be argued that Finnish social assistance is universal by nature. It has to be paid (if applied for), at least in a reduced amount, as long as the requirement of residency is fulfilled. Before the reform, social workers had the opportunity to evaluate reductions beforehand to make sure that a reduction would not endanger the vital subsistence of the client. Indeed, a client can meet the municipal caseworker after Kela has informed the client of a forthcoming reduction, and then the caseworker can make a statement in order to convince Kela that the reduction is unreasonable and may threaten the client's capacity to function within society. Kela is only obliged to inform municipalities afterwards if a client's social assistance is reduced. One caseworker described the situation for young people as follows:

Clients under 25 are at risk of exclusion, and if Kela doesn't inform the municipality of their situation, they might be without any service or activating measures for several months. Their problems become deeper and more complex. When a young person is finally referred to the municipality, it may be too late to contact them. Before, we were able to find the necessary services for young people as soon as it was seen that the need for social assistance wasn't occasional. (Respondent 89, federation of municipalities)

Invisible clients (in Table 1) include young people and immigrants without Finnish, Swedish, or English language skills. Language skills are a necessity in order to apply for social assistance and to access services, and also in everyday life. Kela has organised remote interpreting, but according to the caseworkers, the interpreting services were not seen to be sufficient. The respondents stated that the clients did not know their rights or responsibilities due to misunderstandings. Furthermore, for immigrants, education and employment services are essential, but they do not necessarily have information about these services. The client may have several issues at the same time, which presupposes smooth cooperation between Kela and municipal social work. One social worker wrote:

The position of immigrants is pretty bad. Before, they came to the social work offices and got help on several issues during the appointment, and if there were mistakes in the decisions concerning social assistance, it was easy and quick to fix. Nowadays, Kela customer service officers are not allowed to make decisions themselves, thus they cannot correct mistakes, and they are not able to give the right advice. Too often, they refer clients to the social worker without any decision on basic social assistance. (Respondent 338, mid-size town)

People have needs that are ignored, and the consequences may be severe, especially in the long term. In every case, problems in customer service and cooperation between Kela and municipalities increase financial precarity and uncertainty, which impairs social citizenship (see Goul Andersen, 2012).

The most disadvantaged clients are in the lower righthand corner (in Table 1). Safety net dropouts are those who are mentally exhausted, ill, and have substance misuse problems-or in general, people who have difficulty coping in their everyday lives. They have several needs of (social) services, and they are often entitled to supplementary or preventive social assistance. Support from caseworkers may be a prerequisite for access to necessary health and social services. One caseworker described the clientele as follows: 
The situation is the worst for the mental health patients whose basic social assistance Kela may reduce if they are not able to apply for sick leave or get in contact with the employment office. For people with long-term illnesses, these demands are impossible: They do not have contact with health care, or they are not able to get appointments quickly enough. For some of these clients, even leaving their apartment might be too big of an obstacle. Kela doesn't correct reduced basic social assistance, which results in more decisions being made by the municipality. (Respondent 30, metropolitan area)

Statements like this describe threats to social citizenship. Requirements for disadvantaged people may be unreasonable (see Leibetseder et al., 2017). One social worker wrote:

I am extremely worried about clients with multiple problems, people without language skills, people with mental health problems, people who are not able to leave home, unskilled people, substance abusers, etc. They don't understand or they are not able to function with Kela's decisions. They don't read the decisions, or they are not able to understand them. These problems have shown up as unpaid bills. Social assistance has been directed to the client (not to the renter) and the rent goes unpaid. (Respondent 88 , large city)

Social citizenship was hardly realised for recipients in this group-before or after the reform. According to the caseworkers, the current arrangements seemed to work for those who were healthy and had a good degree of autonomy, i.e., capable clients. However, this typology is not static, as recipients may occupy different positions over time. Citizens have numerous needs and preferences and the given polity influences how their citizenship is constructed (Edmiston, 2017).

\subsection{Targeting within Universalism?}

As stated above, selectivity in some parts of the social security system does not mean giving up on universalism as such. It is a question of the degree of universalism. Next, we utilise the typology and try to identify the groups in the statistics collected from the recipients of social assistance.

According to official national statistics, social assistance was granted in 2018 to 469,694 people $(8.5 \%$ of the whole population) in 306,322 households $(9.9 \%$ of all Finnish households). Social assistance did not seem to be only a final safety net, but rather a top-up benefit for many. The largest group in our classification (see Table 1) consists of capable clients for whom social assistance is more or less only a top-up benefit.

Housing costs are a typical reason to apply for basic social assistance, especially in the central districts where housing costs are relatively high. According to Kela's reg- isters (2019), 45\% of the basic social assistance costs in 2018 were granted for housing costs. Households receiving a top-up to their income or benefits due to housing costs are often clear cases, and basic social assistance can be paid mostly by applying the same practices to all households.

Kela is obliged to refer clients to municipal social services when it observes a need for services. In such cases, clients and their households are in need of targeted services from the municipal social services, and it may also be that in handling benefits, discretion is needed in order to satisfy a client's needs. According to Kela's registers (2019), a little less than half of the households were in need of social services in 2018.

Persistent clients in the typology (see Table 1 ) receive social assistance due to occasional expenses that cannot be covered by a regular income, for instance with unemployment benefits or a pension. These expenses can occur due to hospitalisation or medical prescriptions, for example, which are typical of elderly recipients of social assistance, albeit the receipt of social assistance may not be long-term. This assumption is supported by official statistics, as for the majority of older people $(66.5 \%$ of recipients aged 65 years or older) social assistance was short-term support (1-3 months per year). The total number of short-term recipients was 181,743 in 2018.

Some of the expenses are not covered by basic social assistance but are covered by supplementary or preventive social assistance paid by municipalities. In 2018, a total of 77,747 households received supplementary social assistance, and preventive social assistance was granted to 37,767 households. These households become clients of municipal social work teams when receiving supplementary or preventive social assistance, although not all of them are necessarily in need of services.

The two other identified groups (see Table 1) suffer from a disconnection between cash and care. In other words, they have a need for both social assistance and services but might not receive the latter due to the fact that the benefits and the services are offered by different public organisations. The invisible clients (Table 1 ) also include people who have applied for basic social assistance and are not eligible for it but have a need for social services. In 2018, the number of such households was 28,162 (Kela, 2019). These clients have no obligation to meet a caseworker, even if Kela has observed a need for services and has reported it to the municipality. It is unclear how many of these clients actually receive the services they need.

Another signal for the need for services is situations where basic social assistance is reduced due to sanctioning of the benefits when the recipient has been observed behaving in an improper manner. Kela has nationwide practices to reduce social assistance and sanctions can be applied more systematically than before the reform. Kela has an obligation to inform the municipality in such cases. The number of notifications was 27,584 in 2018. Again, these clients are not obliged to contact the case- 
worker in municipal social work. Targeting within universalism does not work as it should if the clients are left without needed social services.

The number of safety net dropouts (Table 1 ) is difficult to assess, as they are not necessarily reached by Kela or the municipalities and are therefore not on the registers. In the survey, caseworkers mentioned that clients with accumulated social problems are at risk of dropping out of the safety net. According to statistics, 87,445 households were long-term (10-12 months in one year) recipients of social assistance in 2018, which is a strong signal of dropping out of the safety net, as social assistance should provide only temporary support.

\section{Conclusion: The Room for Targeting within Universalism}

We wanted to understand universalism as a social policy principle concerning social assistance recipients. We relied on the concept of social citizenship, as it emphasises social, economic, and democratic rights that we also recognise in Finnish welfare legislation.

We first asked: What is the role of social assistance in the Finnish welfare state? As a Nordic country, Finland is often regarded as a universal welfare state, with meanstesting and targeted benefits playing only a minor role. We argued that targeting does not necessarily contradict the idea of universalism as a policy principle, especially when the focus is on the outcome and individuals' needs are taken into account when allocating resources. Targeting can even be seen as fine-tuning universal welfare, in the sense that it enables more support for people with the greatest needs (Anttonen, Häikiö, Stfánsson, \& Sipilä, 2012, pp. 7-8). According to Finnish legislation, social assistance is meant to be only temporary financial aid, and one of its tasks is to increase participation. This did not change when basic social assistance was transferred to Kela at the beginning of 2017.

We wrote about the degree of universalism, as it has been shown that pure universalism hardly exists. Furthermore, it has been said that the welfare state always includes some idea or some level of universalism. If universalism is scrutinised in terms of procedures, it means that the same policy applies equally to everyone (Anttonen, Häikiö, \& Stefánsson, 2012, pp. 189-191). The centralisation of social assistance was justified by the claim that when nationwide practices would be applied to social assistance, equality for clients would increase. This may be the case for those clients who are only in need of social assistance as a top-up for other income or benefits. According to our analysis, the group of capable clients makes up a big share of the recipients. For them, the national system is better, and Kela might be easier to approach than the municipal social services, especially when only basic social assistance is needed alongside basic social security and the applicant may apply for it electronically. However, when social assistance is utilised as a top-up benefit, it reduces the certainty of monthly income compared to sufficient insurance-based or basic social security; thus it may erode social citizenship, at least for those who have to rely on social assistance for a lengthy period (Edmiston, 2017; Esping-Andersen, 1990, pp. 25-26).

Secondly, we asked: What is the nature of universalism in the final safety net? In principle, the final safety net should bring the less privileged closer to the general standard of society by enhancing their social citizenship. According to the caseworkers in municipal social services, social assistance recipients have too often been left alone to navigate the system without receiving the services they need. This may harm universalism in terms of universal inclusion and social citizenship (see Stéfansson, 2012). However, our typology also highlighted the necessity of targeting within universalism. We recognised invisible clients, persistent clients, and safety net dropouts, and their different needs. The welfare system is not able to offer enough support without acknowledging the diversity of the clientele. The safety net dropouts are especially at risk of exclusion, and it may be necessary to allocate more resources to them. The reform has highlighted that the recognition of individual needs, discretion, and equality may all be necessary elements in the final safety net, but they are difficult to combine. We conclude that the reform has increased individual self-responsibility instead of giving more choices or increasing autonomy for these clients. Therefore, the reform has been a step in the direction of active citizenship instead of supporting the social citizenship of disadvantaged groups (Eggers et al., 2019).

The statistics showed that last-resort social assistance has gained a strong foothold in the Finnish social security system. We do not yet know whether the reform has increased the acceptance of means-testing in the social security system by digitising the application process and hiding the inadequacy of the basic social security or whether citizens see social assistance as more legitimate and the recipients as more deserving. Furthermore, we have relied on the views of municipal caseworkers and register data. The municipal caseworkers meet only some of the recipients-often those who struggle with bureaucracy and who experience difficulties in their lives. Their views cannot be generalised to all recipients. Obviously, we should seek opinions and ask about the experiences of the social assistance recipients. In every case, this article has shown that one reform has multiple outcomes which should be evaluated carefully, especially if universalism is seen as an important social policy principle.

\section{Acknowledgments}

The writers thank the anonymous reviewers and editors for their critical comments. This research was supported by the Strategic Research Council of the Academy of Finland (Decision Numbers 293103 and 312794). 


\section{Conflict of Interests}

The authors declare no conflict of interests.

\section{References}

Anttonen, A., \& Sipilä, J. (2012). Universalism in the British and Scandinavian social policy debates. In A. Anttonen, L. Häikiö, \& K. Stefánsson (Eds.), Welfare state, universalism and diversity (pp. 16-41). Cheltenham: Edward Elgar.

Anttonen, A., Häikiö, L., \& Stefánsson, K. (2012). The future of welfare state: Rethinking universalism. In A. Anttonen, L. Häikiö, \& K. Stefánsson (Eds.), Welfare state, universalism and diversity (pp. 187-196). Cheltenham: Edward Elgar.

Anttonen, A., Häikiö, L., Stefánsson, K., \& Sipilä, J. (2012). Universalism and the challenge of diversity. In A. Anttonen, L. Häikiö, \& K. Stefánsson (Eds.), Welfare state, universalism and diversity (pp. 1-15). Cheltenham: Edward Elgar.

Blomgren, S., Karjalainen, J., Karjalainen, P., Kivipelto, M., Saikkonen, P., \& Saikku, P. (2016). Sosiaalityö, palvelut ja etuudet muutoksessa [Social work, services and benefits in a state of flux]. Helsinki: National Institute for Health and Welfare.

Bradshaw, J., \& Terum, L. I. (1997). How Nordic is the Nordic model? Social assistance in a comparative perspective. Scandinavian Journal of Social Welfare, 6(4), 247-256.

Edmiston, D. (2017). Welfare, austerity and social citizenship in the UK. Social Policy \& Society, 16(2), 216-270.

Eggers, T., Grages, C., \& Pfau-Effinger, B. (2019). Selfresponsibility of the "active social citizen": Different types of the policy concept of "active social citizenship" in different types of welfare states. American Behavioral Scientist, 63(1), 43-64.

Esping-Andersen, G. (1990). The three worlds of welfare capitalism. Cambridge: Policy Press.

Frederiksen, M. (2018). Varieties of Scandinavian universalism. Acta Sociologica, 61(1), 3-16.

Friese, S. (2014). Qualitative data analysis with ATLAS.ti. London: SAGE.

Gough, I. (2019). Universal basic services: A theoretical and moral framework. The Political Quarterly, 90(3), 534-542.

Goul Andersen, J. (2012). Universalization and deuniversalization of unemployment protection in Denmark and Sweden. In A. Anttonen, L. Häikiö, \& K. Stefánsson (Eds.), Welfare state, universalism and diversity (pp. 162-186). Cheltenham: Edward Elgar.

Jacques, O., \& Noël, A. (2018). The case for welfare state universalism, or the lasting relevance of the paradox of redistribution. Journal of European Social Policy, 28(1), 70-85.

Kallio, J., \& Kouvo, A. (2015). Street-level bureaucrats' and the general public's deservingness perceptions of social assistance recipients in Finland. Social Policy and Administration, 49(3), 316-334.

Kela. (2019). Statistics on basic social assistance. Kela. Retrieved from https://www.kela.fi/web/en/statisticson-basic-social-assistance

Kettunen, P., \& Petersen, K. (2011). Introduction: Rethinking welfare state models. In P. Kettunen \& K. Petersen (Eds.), Beyond welfare state models: Transnational historical perspectives on social policy (pp. 1-15). Cheltenham: Edward Elgar.

Kildal, N., \& Kuhnle, S. (2005). The Nordic welfare model and the idea of universalism. In N. Kildal \& S. Kuhnle (Eds.), Normative foundations of the welfare state: The Nordic experience (pp. 13-33). London: Routledge.

Korpi, W., \& Palme, J. (1998). The paradox of redistribution and strategies of equality: Welfare state institutions, inequality, and poverty in the western countries. American Sociological Review, 63(5), 661-687.

Kuhnle, S. (2011). International modelling in the making of the Nordic social security system. In P. Kettunen \& K. Petersen (Eds.), Beyond welfare state models: Transnational historical perspectives on social policy (pp. 65-81). Cheltenham: Edward Elgar.

Kuivalainen, S., \& Nelson, K. (2012). Eroding minimum income protection in the Nordic countries? Reassessing the Nordic model of social assistance. In J. Kvist, J. Fritzell, B. Hvinden, \& O. Kangas (Eds.), Changing social equality: The Nordic welfare model in the 21st century (pp. 69-87). Bristol: Policy Press.

Leibetseder, B., Gubrium, E., Dierckx, D., Fluder, R., Hauri, R., \& Rayemaeckers, P. (2017). Subsidiarity and social citizenship: Social assistance schemes in Austria, Belgium, Switzerland and Norway. International Journal of Social Welfare, 26(4), 353-365.

Marchal, S., Marx, I., \& van Mechelen, N. (2014). The great wake-up call? Social citizenship and minimum income provisions in Europe in times of crisis. Journal of Social Policy, 43(2), 247-267.

Ministry of Social Affairs and Health. (1997). Social assistance act (No. 1412/1997). Helsinki: Ministry of Social Affairs and Health. Retrieved from https://www.ilo.org/dyn/natlex/natlex4.detail? p_lang=en\&p_isn $=49653 \& p \_c o u n t r y=F I N \&$ p_classification $=15.05$

National Institute for Health and Welfare. (2019a). Perusturvan riittävyyden arviointi 2015-2019 [Evaluation report on the adequacy of basic social security 2015-2019]. Helsinki: National Institute for Health and Welfare. Retrieved from http://urn.fi/URN:ISBN: 978-952-343-296-3

National Institute for Health and Welfare. (2019b). Toimeentulotuki 2018 [Social assistance statistics 2018]. Helsinki: National Institute for Health and Welfare. Retrieved from https://thl.fi/fi/tilastot-jadata/tilastot-aiheittain/aikuisten-sosiaalipalvelut/ toimeentulotuki/toimeentulotuki

Niemelä, H., \& Salminen, K. (2006). Social security in Fin- 
land. Helsinki: Finnish Centre for Pensions.

Parliament of Finland. (2014a). HE 358/2014 vp: Hallituksen esitys eduskunnalle laeiksi toimeentulotuesta annetun lain ja kunnan peruspalvelujen valtionosuudesta annetun lain muuttamisesta [Bill to change the Social Assistance Act and the Act for the Municipal Services Subsidy by the state]. Helsinki: Parliament of Finland. Retrieved from https://www.eduskunta. $\mathrm{fi} / \mathrm{Fl} /$ vaski/sivut/trip.aspx?triptype=ValtiopaivaAsiat \&docid=he+358/2014

Parliament of Finland. (2014b). Sosiaali- Ja Terveysvaliokunnan Mietintö [Committee on social affairs] (Report 54/2014-HE 358/2014). Helsinki: Parliament of Finland. Retrieved from https://www. eduskunta.fi/Fl/vaski/Mietinto/Documents/stvm_54 +2014.pdf

Parliament of Finland. (2016). Sosiaali- Ja Terveysvaliokunnan Mietintö [Committee on social affairs] (Report 33/2016-HE 217/2016). Helsinki: Parliament of Finland. Retrieved from https://www. eduskunta.fi/FI/vaski/HallituksenEsitys/Documents/ HE_217+2016.pdf

Petersen, K. (2011). National, Nordic and trans-Nordic: Transnational perspectives on the history of the Nordic welfare states. In P. Kettunen \& K. Petersen
(Eds.), Beyond welfare state models: Transnational historical perspectives on social policy (pp. 41-64). Cheltenham: Edward Elgar.

Stéfansson, K. (2012). What is in a word? Universalism, ideology and practice. In A. Anttonen, L. Häikiö, \& K. Stefánsson (Eds.), Welfare state, universalism and diversity (pp. 42-68). Cheltenham: Edward Elgar.

Turner, B. S. (2009). T. H. Marshall, social rights and English national identity. Citizenship Studies, 13(1), 65-73.

van Oorschot, W., \& Roosma, F. (2015). The social legitimacy of differently targeted benefits (Discussion Paper No. 15/11). Antwerp: Herman Deleeck Centre for Social Policy.

van Oorschot, W., \& Roosma, F. (2017). The social legitimacy of differently targeted welfare and welfare deservingness. In W. van Oorschot, F. Roosma, B. Meuleman, \& T. Reeskens (Eds.), The social legitimacy of targeted welfare: Attitudes to welfare deservingness (pp. 3-36). Cheltenham: Edward Elgar.

Varjonen, S. (2020). Institutional evolution and abrupt change: Reforming the administration of social assistance in Finland. International Journal of Social Welfare, 29(1), 62-70.

\section{About the Authors}

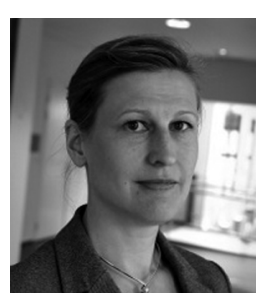

Paula Saikkonen (PhD) works at the Finnish Institute for Health and Welfare. Her research work has focused on welfare states or social security. She is one of the editors and the writers of the book The Relational Nordic Welfare State, Between Utopia and Ideology (2019). Currently, she works in two research projects funded by the Strategic Research Council of the Academy of Finland.

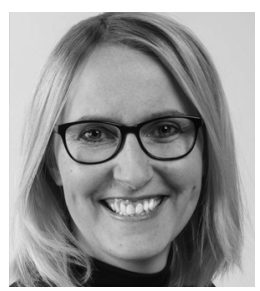

Minna Ylikännö (PhD) works as Head of Research Group in the Social Insurance Institution of Finland (Kela). Her main research interests include unemployment, employment policies, well-being, and minimum income schemes. Currently, she is engaged in several research projects concerning, e.g., Finnish basic income experiment, social assistance, and the impacts of sudden structural change in ecosystems. 